\title{
Classification and Categorization: Linguistic and Cultural Conceptualization of Time in the YiJing
}

\author{
Yancheng Yang ${ }^{1,2,3}$ \\ ${ }^{1}$ School of Foreign Languages/Institute of Language and Cognition, Hunan University, Changsha, China \\ ${ }^{2}$ School of Foreign Languages, Luoyang Institute of Technology and Science, Luoyang, China \\ ${ }^{3}$ CRLAO, INALCO, Paris, France \\ Correspondence: Yancheng Yang, School of Foreign Languages, Hunan University, 410082 Changsha, China. \\ E-mail: yanchengyang@hnu.edu.cn
}

Received: October 11, 2019 Accepted: November 19, 2019 Online Published: December 15, 2019

doi:10.5539/ijel.v10n1p166 URL: https://doi.org/10.5539/ijel.v10n1p166

\begin{abstract}
This paper investigates how concepts of time in the YiJing (here 易经 YiJing refers to the 经文 Jing text in the ancient Chinese work The Book of Changes) are organized and expressed in terms of language structure and cultural practice, especially with regard to the lexicalization of time intervals and temporal landmarks. The way in which time is conceptualized in the YiJing is very special. The purpose of this study is to explore the cognitive and cultural construals of time with the language of real-world experience. With reference to the Cognition-Culture interface, the YiJing text has been used as a corpus to investigate the encoding of time, and the following categories of temporal conceptualization are found according to the different kinds of usages: 1 . Metaphoric temporal usage, which is a metaphoric expression of time, such as "a long time" or "quasi-calendar time"; 2. Concepts of time, involving quantification of time: for example, the processes of waxing, waning, declining and growing of the moon that illustrate the quality of alteration associated with time; 3 . Event-based intervals, such as “巳日 Siri Day Si” “先甲三日 three days before Day Jia and 后甲三日 three days after Day Jia"; 4. The propitious or opportune time, which is the notion of time as the right time to do something, or the right time which gives a chance to engage in the activity at the right time once it brings good luck. What is more interesting is that from all of these examples in the YiJing, the concepts of time are directly or indirectly linked with either metaphor or the event-based time concept, such as celestial bodies (the sun, moon and stars) or the ritual system, which is specific to a particular culture of the YiJing in ancient China.
\end{abstract}

Keywords: conceptualization of time, linguistic and cultural, the YiJing, event-based time concept, metaphor, classification and categorization

\section{Introduction}

In different languages and cultures, the ways of encoding and thinking about time can differ. For instance, Chinese President Xi's New Year message on December 31, 2018 in example (1) shows the conceptualization of time in China.

(1) 岁月不居, 时节如流。(孔融《论盛孝章书》)

Suìyuè bù jū, shijié rú liú.

Year month NEG stay, time season like flowing.

Time will never keep still, and the seasons always change as the river flows.

It is worth pointing out that this is a classical sentence quoted from Kong Rong's letter in the Han dynasty. The whole sentence is given in example (2).

(2) 岁月不居, 时节如流, 五十之年, 忽焉已至。(孔融 《论盛孝章书》)

Suìuè bù jū, shijié rú liú, wǔshí zhī nián, hū yān y̌̌ zhì.

Year month NEG stay, time season like flowing, fifty of years, suddenly how already arrive.

Time will never keep still, and the seasons always change as the river flows. Suddenly you are 50 years old, but I am two years older. 
Thus, it seems that people from different eras may have a similar conceptualization of time, but in fact the conceptualization of time is a very complex issue that is addressed in many fields and disciplines. There have been numerous previous studies on the conceptualization or representation of time in the domains of philosophy (e.g., Minkowski, 1964; Silva Sinha et al., 2012), anthropology (e.g., Schieffelin, 2002; Postill, 2002; Abu-Shams \& González-Vázquez, 2014), physics (e.g., Birth, 2012; Wei \& Wang, 2014), cosmology (e.g., Hubert, 1999), biology and neuroscience (e.g., Levine, 1998; Núñez \& Cooperrider, 2013; Núñez et al., 2012), cognitive science (e.g., Levinson, 2003; Núñez \& Cornejo, 2012; Majid, et al., 2013; Majid, et al., 2013), culture and linguistics (e.g., Moore, 2006, 2014; Núñez \& Sweetser, 2006; Sinha et al., 2011), and other fields (e.g., Tenbrink, 2011). The past research mainly indicates that the nature of time has been an on-going puzzle for all of philosophy and science, including language and cognition. However, few studies have explored the conceptualization of time with reference to ancient Chinese, let alone by referring to the YiJing text in which the original time concepts of ancient China can be clearly seen.

As is well known, YiJing is the first of the Five Confucian Classics in China and can be seen as the wellspring of both Confucianism and Taoism. To some extent, YiJing can represent the main ancient Chinese traditional culture. YiJing is written with examples from the daily life in the ancient period; not only ordinary events happening every day, but also special events like rituals, war, various celestial movements and natural phenomenon like solar eclipse, which are closely related to the original conceptualization of time in ancient China.

Wang et al. (2014) held that there is a mathematical-astronomical concept of time in the YiJing which is the basis of a highly developed calendar. There is also a record of the space-time model, in which time is considered to be one of the extended coordinates. Tan (2014) proposed that time and space are one unity, and that the essence of space is also closely related with time. The temporal concept in the YiJing is a kind of related, systematic time concept. Yang et al. (2007) proposed that the YiJing is not only an achievement of the wisdom of the ancient Chinese nation, but also established the humanistic time conception (i.e., time related with human activity or life events, rather than physical, psychological time). The humanistic time conception of the YiJing has had an important influence on Chinese culture and even on other cultures around the world.

Huang and Zürcher's (1995) argue that time and space are "transcendental"; that is, they are "a-historical, a-cultural and indifferently shared by all human beings as long as they are rationally human" (pp. 3-10). A number of Taiwanese scholars who contributed to Huang and Zürcher's book have examined "Time and Space in Chinese Culture," but so far, few Chinese scholars have focused on time and space study from the perspective of cognitive cultural linguistics. One example is Lin (1995), whose study is closely related to the conceptualization of time. Lin showed us that "position (位 wei) and time (时 shi) are closely related or connected in the YiJing. The meaning of a time is a function of position, the significance of a position also depends on time. That is to say, a certain position will be a place at a certain time. These are the formative principles of position, conceived as a function of time. The sequence of lines from the first, second, third, fourth, fifth, up to the sixth depicts the dynamic stages of a temporal condition" (Lin, 1995, pp. 89-113). By considering the complete situation depicted in the six-line positions, one can discern a hexagram's "hexagram time." Moreover, it will present the horizontal dimension of a certain temporal process. The relationship between "time and position" is always presented in the context of a particular situation. Also, Li (1995) examined the culture of China from the vertical perspective, viewing it as consisting of an upper-level elite culture and a lower-level popular culture. That is to say, the cultural time and space and their concretizations are all embodied and lived among by Taiwanese folks.

Time in ancient China was mainly registered in terms of one's observation of nature, as direct evidence of one's abstract thinking is rooted in direct observation of concrete objects and events ( $\mathrm{Su}, 2016)$. The significance of the YiJing is assumed as it is representative of time conceptualization in Chinese. Event-based time is defined by the events from which their names usually derive, while event-based time intervals may be based upon natural cycles, such as the diurnal and seasonal cycles, or they may be based on social norms and conventions (Silva Sinha et al., 2012; Sinha \& Gärdenfors, 2015). The YiJing text is made up of different events where every 卦gua is one event, and every 爻yao is a different period of that event, so we can closely connect the time concept in the YiJing with event-based time, especially with metaphoric event, which is also our hypothesis.

We believe that the usage of the temporal concept is to show the continuity and sequence of the process of motion. Human beings first recognized this characteristic of time by directly reflecting the periodic process of the medium, that is, some periodic changes in the natural world such as the sun rising and setting, alternating day and night, the waxing and waning of the moon, winter going and spring coming, thus making a standard for measuring the length of time and determining the time sequence. We can therefore intuitively observe time and grasp the concept of time. In short, judging from the available data, we explore the classification and 
categorization of different concepts of time, and different linguistic conceptualizations of time in the YiJing, especially the time interval system used in ancient China. One question still remains unanswered here: How does the written text in the YiJing convey the concepts of time? This is also our main research question.

\section{The Temporal Concept and Linguistic Representation in the YiJing}

The point I shall discuss first is "What is a temporal word?" The Modern Chinese Dictionary (2016) defines a temporal word as a noun that expresses time, such as past, present, future, morning, etc. According to Zhang (1953), temporal words are regarded as one of the noun categories, which are further divided into four sub-categories: a certain time; not referring to a certain time; a certain interval or period of time; the "front and back" order of a certain thing, but not a certain date or point in time (Zhang, 1953, pp. 141-142). The concepts of past, present and future were mainly derived from concrete locative senses such as up and down, left and right, or east and west.

Zhu (2003) pointed out that the temporal word is an object that can be used after “在 $z a i$ in," “到dao to," “等到 dengdao wait for" and "体词 tici tense word" that can use "this time" and "that time" to refer to, for example, 宋朝 Songchao Song Dynasty, 1930, 立春 Lichun beginning of spring, 从前 congqian once, and 以前 yiqian before. All temporal words can represent time, but words that represent time are not necessarily temporal words (Zhu, 2003, p. 43). For example, “half day, two years" is a quantitative word, and “时间 shijian time、时 候 shihou occasion、功夫 gongfu moment" is a general noun, not a temporal word. Zhao (1979) presented the same idea as Zhu, and also pointed out that in terms of semantics, temporal words refer to somewhere in the flow of time from ancient times to the present, such as “周朝 Zhouchao Zhou Dynasty,” or relative to the speech time, such as "ancient time." A cross-cultural study of the metaphorical representation of time was carried out by Zhou (2000). He used two main ways to study metaphorical sentences of time in both Chinese and English cultures. They are the "What is time?" questionnaire and sentences of time metaphor through literary works, quotation books, etc. in both languages. He found the same structural dimensions of time in the two cultures. In this paper, we define temporal words as the expressions or indexicalization that can represent the process of the conceptualization of time, both linguistically and culturally.

The YiJing is one of the most important masterpieces in ancient Chinese. Using the related material in the unearthed literature, we can find the appearance of time concepts in the YiJing, which will be helpful for further study ( $\mathrm{Li}, 2005)$. Some words in the Shanghai Museum version of the YiJing (Pu, 2014) represent the outstanding characteristics of the early ancient Chinese language. In this paper, the YiJing text I mainly use is the Shanghai Museum Manuscript (the earliest manuscript, dating from about the Late Warring States Era), while some missing parts are taken from the Wangjiatai Bamboo-Strip Manuscripts and the Fuyang Manuscript for reference.

According to Shaughnessy's (2014) introduction, we know that the core of the YiJing text is the 64 graphs or “pictures" (called gua hua 卦画 in Chinese); there are six lines in each guahua, either whole (-) or broken (--). In the West these have come to be known as hexagrams (gua 卦). Each of these 64 hexagrams is supplied with a name and seven brief texts including one guaci and six yaoci: a "hexagram statement" (guaci 卦辞) is understood to represent the entire hexagram, and "line statements" (yaoci 爻辞) for each of the six lines. Little more than the hexagram name and one or more injunctions for (or against) certain actions are often included in the hexagram statement, which is usually quite formulaic. From the bottom of the hexagram to its top, we can count all the line statements, "each one introduced by a sort of tag identifying its place within the hexagram and the nature of the line (whether whole or broken) to which it is attached" (Shaughnessy, 2014, p. 23). The bottom line is called "First" (chu 初), the top line "Top" (shang 上), and the intervening lines are simply numbered "Second" (er 二), “Third" (san 三), “Fourth" (si 四), and "Fifth" (wu 五). All of the lines together are referred to as "nine" (jiu 九), which is understood to be yang (i.e., "sunny," understood in the traditional Chinese worldview to be one of the two basic attributes of all things), and the broken lines are referred to as "Six" (liu 六), which is understood to be yin (i.e., "shady," the second basic attribute ). Such tags as "First Six" (chu liu 初 六), “nine in the Third” (jiu san 九三), and “Topmost Six" (shang liu 上六) are usually given by the combination of these two features. Basically, each hexagram includes six lines, where each line is called a yao. From the bottom to the top, there are six yaos and they have special names in the YiJing. Two parts are mainly contained in the YiJing text; in general, one is called guaci, and the other is called yaoci.

The YiJing has 64 hexagrams, where each hexagram symbolizes the law of development, and the change of one thing or one phenomenon has a certain background. This certain background which supplies an explanation for the meaning of this hexagram is called time (Huang \& Zhang, 2007). Wilhelm (1950) mentioned Time in the appendix of his translation. His definition is similar to that of Huang and Zhang's, and is as follows, "The 
situation represented by the hexagram as a whole is called the time" (Huang \& Zhang, 2007, p. 463). He also believed that the time of a hexagram is determinative of the meaning of the situation as a whole, on the basis of which the individual lines receive their meaning. A given line can be favorable or unfavorable now, according to the time determinant.

The time in the YiJing is one kind of certain cultural construction based on an event (the existence of a cultural dimension or cultural specific). Time conceptualization in the YiJing is original, and includes natural time and "life" time (a situation, fate fortune, social position, weal and woe, etc.) The temporal concept in the YiJing can also reflect people's life in the Yin Zhou dynasty. The term “时 shi time" in the YiJing only appears once: that is the line comment on the fourth line of the Kuei Mei 归妹 Hexagram.

(3) 归妹卦: 九四, 归妹想期, 迟归有时。

Gū̃ mèi guà: Jiǔsì, guī mèi qiānqí, chí guī yǒushí.

Nine four, marrying sister delay time, late marriage have time.

The marrying maiden draws out the allotted time. A late marriage comes in due course.

Here “时 shi time" in example (3) is not about the real time concept, but means waiting for a good chance (待时 daishi).

In this paper I will take the Hexagram Judgments (卦辞guaci) and the Linear Judgments (爻辞yaoci) as examples to perform the corpus analysis. I chose 34 Hexagram Judgments (gua) and Linear Judgments (yao) randomly as my first priming corpus samples to perform the concordance and collocation analysis. A mixed methodology combining qualitative (interpretation) with quantitative (concordance and collocation) analysis was adopted in this study.

\section{Classification and Categorization of the Conceptualization of Time in the YiJing}

The concept of time has always existed with two kinds of prototypical views of time, namely the measurement of time and the flowing time (the "flow" or passage of the "River of Time"). There is ample evidence that in the YiJing text the way of describing time, or the temporal expression, is very different in terms of different classification standards. For the analysis, the criteria of classification used are mixed semantic classification (as in section 3.1), syntactic classification (as in section 3.2), and calendrical terms (as in section 3.3). Ad hoc terms and definitions are used, but they do not contribute greatly to the understanding of the time concept. According to the objects or carriers they are used for, the temporal concept can be divided into five categories, which are the time concept according to the law of operation, position and deformation of the celestial body; the time concept using the "Cardinal number + temporal unit word" construction; expressing the time concept with the branches and the stems; describing the time concept with the activities of the crowd or certain groups and certain social customs; and directly describing the time concept in terms of temporal words such as year, month and day. The fifth category can also be divided into several categories according to the length of time indicated; that is, it relates to the concept of the measurement of time. From the perspective of flowing time, there are categories that represent the past, present, and future, which are closely related to deictic time.

\subsection{Describing the Time Concept According to the Law of Operation, Position and Deformation of the Celestial Bodies}

The token and frequency of the first category is 11/37, 37 examples from (4) to (40) are included in the priming corpus analysis. It is called the quantification of time, and is mainly about the processes of waxing, waning, declining and growing that illustrate the quality of alteration associated with time. Examples (4) and (5) show "Quantification of time” by the expression of “月几望 yuejiwang moon almost full."

(4)《小畜·上九》: “既雨既处, 尚德载, 妇贞, 厉。月几望, 君子征凶。”

《Xiăo chù · shàng jiǔ》: "jì yŭ jì chù, shàng dé zăi, fù zhên, lì o yuè jŭ wàng, jun zǐ zhēng xiōng。”

Already rain already stays here, good moral carry, woman persists, harmful. Moon almost full, gentleman go on, inauspicious.

Top 9: Now it has started raining and you have reached a place [to rest], [you should stay here], value your good deeds. To carry the woman on [through this weather] may seem correct but will be harmful. Furthermore, the moon has just come out; it will be bad for the wise person to go on [at such a late hour].

(Baynes \& Wilhelm, 1997; the following examples' translations are taken from the same sources, omitting quotations. The I Ching, or Book of Changes - Yi Jing I. 09.)

(5)《中孚·六四》: “月几望, 马匹亡, 无处。” 
《Zhōng fú · liù sì 》 : “yuè jǔ wàng, mă p̌̌ wáng, wú jiù 。”

Moon almost full, horse equipment lost, no blame.

Fourth 6: A group of horses run away when it is nearly full moon, and who can blame them?

(The I Ching, or Book of Changes - Yi Jing I. 61.)

Here “月几望 yuejiwang moon almost full” in these two examples means the full moon or the moon waxing to the full. The other similar example in the YiJing text which uses “月几望” is example (6):

(6)《归妹·六五》: “帝乙归妹, 其君之袂, 不如其娣之袂良; 月几望, 吉。”

《Gū̃ mèi · liùwǔ》: "Dì yì guĩ mèi, qí jūn zhī mèi, bùrú qí dì zhī mèi liáng; yuè jǔ wàng, ji.."

Emperor Yi returns sister, his prince MOD clothes, not as good as his serving maid. Moon almost full, fortune.

I gave his daughter to the sovereign in marriage. The embroidered garments of the princess were not as gorgeous as those of the serving maid. The moon is nearly full; it brings good fortune.

(The I Ching, or Book of Changes - Yi Jing I. 54.)

In this example, “月几望” also indicates that the moon is nearly full. “日昌 ri ze” in Example (7) means sundial, which describes the process of the sun's movement. The sun's movement in one day can take different forms, which we can verify in the other examples.

(7) 《离·九三》: “日旲之离, 不鼓午而歌, 则大薪磋, 凶。”

《Li · jiǔ sān》: "rì zè zhī lí, bú gǔ fŏu ér gē, zé dà dié cuō, xiōng。”

Sundial MOD leave, NEG beat pots while sing, then old age come sigh, inauspicious.

Third 9: It is bad [if you sit] in the light of the sunset not beating pots while singing, but only lamenting your old age.

\section{(The I Ching, or Book of Changes - Yi Jing I. 30.)}

As illustrated in Example (8), “日中 rizhong” means midday or noon. Using the sun's trajectory can mark the times of day (Boroditsky \& Gaby, 2010): both “日是 ri ze sundia” and “日中 rizhong noon” here can express a point in time or a period of time in terms of the sun's movement throughout the day.

(8)《丰》卦辞: “丰, 亨,王假之,勿忧,宜日中。”

《Fēng》 guà cí : "fềng, hēng, wáng jiă zhī, wù yōu, yí rì zhōng。”

FENG, go well, King deceives MOD, NEG worry, proper midday.

There is abundance and things go well, so it is quite appropriate that the king is resting and does not worry, [even] in the middle of the day.

(The I Ching, or Book of Changes - Yi Jing I. 55.)

Here “昼日zhouri” in Example (9) means daytime. The original temporal concept comes from dividing the day and night. At that time, the ancient people obeyed their original daily routine of working in the daytime and sleeping at night.

(9)《晋》卦辞: “康侯用锡马蕃庶, 昼日三接。”

《Jìn》 guà cí : "kāng hóu yòng xī mă fān shù, zhòu rì sān jiē。”

Kanghou use horses breed a multitude, day and night three times meet.

Progress is similar to when the Marquis Kang used the horses he was bestowed with, to breed a multitude. He mated horses three times a day.

(The I Ching, or Book of Changes - Yi Jing I. 35.)

The natural or agricultural basis of event-based time intervals can also be found in the YiJing text. For example, “旬 xun ten days” in Example (10) can be expressed in the following way.

(10)《丰·初九》: “遇其配主, 虽旬无处。”

《Fèng · chū jiǔ»: "yù qí pèi zhŭ, suī xún wú jiù。

Meet own mate master, although the ten-day period of a month no blames.

When you meet with your mate, you will not receive any blame even if you are equals. 
(The I Ching, or Book of Changes - Yi Jing I. 55.)

As illustrated in example (10), “旬” here means a ten-day period, which is a time interval. In the YiJing text, ancient people could also use “日中 rizhong noontime" +“斗 dou star" to record time intervals, such as in examples (11) and (12).

(11)《丰·六二》: “丰其蔀, 日中见斗, 往得疑疾, 有孚发若, 吉。”

《Fêng · liù èr》: "fêng qí bù, rì zhōng jiàn dòu, wăng dé yí jí, yǒu fú fā ruò, jí。”

Bright its hidden part, day middle sees dou star, go gain suspect and illness, have believed express loyalty, auspicious.

There is such an abundance of clouds, that the plough can be seen at noontime. You will be distrusted when you take action; you will have good fortune when you act with sincerity.

(The I Ching, or Book of Changes - Yi Jing I. 55.)

(12)《丰·九四》: “丰其蔀, 日中见斗; 遇其夷主, 吉。”

《Fèng · jiǔ sì》: "fềng qí bù, rì zhōng jiàn dòu; yù qí yí zhǔ, jí。”

Bright its hidden part, day middle sees dou star; Meet your master, good fortune.

There is such an abundance of clouds that the plough can be seen at noontime. If you meet with your master, you will have good fortune.

(The I Ching, or Book of Changes - Yi Jing I. 55.)

In these two examples, “日中 rizhong noontime" shows the change in position by "using the sun's trajectory to mark the time" of day (Boroditsky \& Gaby, 2010). That is the change of the seasons or the passing of hours at night. There are other similar examples such as (13) and (14) below in the YiJing text.

(13)《丰》卦辞: “丰, 亨, 王假之, 勿忧, 宜日中。”

《Fēng》 guàcí: "Fēng, hēng, wáng jiă zhī, wù yōu, yí rì zhōng."

Feng, good, King deceived it, not worry, proper in the middle day.

Abundance has success. The king attains abundance. Do not be sad; be like the sun at midday.

(I Ching, the Book of Changes - Yi Jing I. 55.)

(14)《丰·九三》: “丰其沛, 日中见昧, 折其右肱, 无处。”

《Fēng · jiǔsān》" "Fēng qi pèi, rì zhōng jiàn mèi, zhé qí yòu gōng, wú jiù."

Feng Qipei, in the middle of the day seeing star, folding his right arm, innocent.

The underbrush is of such abundance that the small stars can be seen at noon. He breaks his right arm. No blame.

(The I Ching, or Book of Changes - Yi Jing I. 55.)

Additionally, we made a number of observations based on analysis of the results. It is worth pointing out that the grammatical structure of the above expressions can be classified into the following three kinds: the subject-predicate structure as in “日旲 rì zè̀, 月几望 yuè jǔ wàng”; the parallel structure such as in “昼日 zhòu rì”; and the modifier-head construction such as “日中 rì zhōng." In this part, we use the following two ways to show the conceptualization of time in ancient China: Describing the time according to the position of the sun or the shadow of the sun: 日中 rì zhōng, 日旲 rì zè; Describing the time by the law of the moon and the moon and its deformation: 月几望 yuè jŭ wàng, 旬 xún. We further propose that this classification belongs to "Concepts of time, involving Quantification of time," for example, the processes of waxing, waning, declining and growing that illustrate the quality of alteration associated with time.

\subsection{The Time Concept Using the "Cardinal Number + Temporal Unit Word" Construction}

The token and frequency of the second category is $15 / 37$. We can see that the "Cardinal number + temporal unit word" construction often appears in the YiJing. The words that express time in the YiJing are often combined with numerals, and the time concept is clearly conveyed. This expression is the main form of calendar time. The calendar time is a time series in which the positional order of the time is calculated and established according to the customary reference, thereby indicating the year, season, month, date, time record, and the time series. Days, months and years are the prototypical time units. Here are some examples of the use of numeral systems for time reckoning (mostly calendars). In fact, the counting of temporal units involves abstraction of TIME AS OBJECT and does not necessarily dictate a fixed temporal event. 
(15)《屯·六二》: “屯如邅如, 乘马班如, 罒寇, 婚媾, 女子贞, 不字, 十年乃字。”

《Tún·liù èr》: "tún rú zhān rú, chéng mă bān rú, fěi kòu, hūn gòu, nü zǐ zhēn, bú zì, shí nián năi zì。”

Village RU no move forward RU, carry horse carriage separate RU, bandit and suitors, girl persists, NEG marry, ten years will marry.

Second 6: [He tries to] build up [her confidence in him] by driving [her] around in a horse carriage. Although he is not a bandit but a suitor, a woman acting correctly will not agree [because of his behavior], but after a long time she will.

(The I Ching, or Book of Changes - Yi Jing I. 03.)

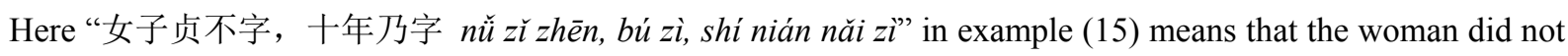
fall pregnant for a long time, and she did not have children for a long time after marriage. After many years, she finally gave birth to a child. The “十年 shinian decade" here does not really represent the tenth year. It only means a long time to express “不字 buzi no child."

(16)《复·上六》: “迷复, 凶, 有灾青。用行师, 终有大败, 以其国君凶, 至于十年不克征。”

《Fù · shàng liù》: "mí fù, xiōng, yǒu zāi shěng。 yòng háng shī, zhōng yǒu dà bài, y̌̀ qí guó jun xiōng, zhì yú shí nián bủ kè zhēng。"

Lost return, woe, have disaster Sheng. Use march army, final have great defeat, cause MOD the country's lord woe, arrive in ten years NEG march and fight.

Top 6: If you return [to the battle ground] with an unfocused [attack], it will go badly. If there is a natural disaster or an eclipse and the army is being sent forth [in spite of this], it will end with a great defeat caused by the country's lord [who gave the order]. This will be bad; for a very long time you cannot attack.

(The I Ching, or Book of Changes - Yi Jing I. 24.)

In this example (16), the expression means that when losing the right path and returning, there will be danger and disaster. When combatting the enemy, one will eventually be defeated. When governing the country, the monarch is in danger and the national strength cannot be restored for a long time. The so-called “十年不克征 shí nián bú kè zhēng” expresses the harm of the slogan of “迷复 mí fü” and means not being able to fight for many years. “Ten years" here is not the specific usage (not referring specifically to ten years), but just means a long time.

(17)《颐·六三》: “拂濒, 贞凶, 十年勿用, 无做利。”

《Yí liù sān》: "fú yí, zhēn xiōng, shí nián wù yòng, wú yōu lì。”

Clear nourishment, suffer woe, ten years not use, no good benefit.

Third 6: Turning away from nourishment, perseverance brings misfortune. Do not act thus for ten years. Nothing serves to further.

(The I Ching, or Book of Changes - Yi Jing I. 27.)

As illustrated in example (17), here it means that there is no need to support the nourishment. If you persist and do not change, there will be sinister dangers, and nothing will happen for many years. There is also no benefit (Liao, 2012, 2015). The “ten years" here also means a long time for “勿用 wuyong do not use”; it does not just mean ten years. Therefore, the "ten years" in these three examples express the meaning of "many years" or "a long time," rather than precisely ten years. In comparison in the following examples, there is no essential difference between the meaning of "three years," "three years old" and "seven days."

(18)《同人·九三》: “伏戎于䒭, 升其高陵, 三岁不兴。”

《Tóng rén · jiǔ sān》: "fú róng yú măng, shēng qi gāo líng, sān suì bú xìng。”

Hide army in hill, climb up the high hill, three years of age NEG march.

Third 9: Fellows hide their weapons in the bushes, go up into the high hills [to lay low] and do not rise for a long time.

(The I Ching, or Book of Changes - Yi Jing I. 13.)

In example (18), it means that the soldiers were lurking amongst the grasshoppers, and some people arbitrarily boarded Gaoling, exposing the target, leading to a big defeat, and then did not start another war for many years (Liao, 2012, 2015). The so-called “三岁不兴 sān suì bú xing” does not mean only three years; in terms of defeat, war cannot last for many years. “三岁 sansui three years old" in examples (19) and (20) also indicate that there is a long time, but not three years. 
(19)《坎·上六》: “系用徽绳, 真于从棘, 三岁不得, 凶。”

《Kăn · shàng liù》 : “xì yòng huī shéng, zhēn yú cóng jí, sān suì bú dé, xiōng。

Tie use cord rope, place among thorny bush, three years of age NEG gain, woe.

Top 6: Tied up with rope and cord and placed among thorny bushes, he achieved nothing for a long time [anything]. This is bad.

(The I Ching, or Book of Changes - Yi Jing I. 29.)

(20)《困·初六》: “雇困于株木, 入于幽谷, 三岁不续。”

《Kùn · chū liù》: "tún kùn yú zhū mù, rù yú yōu gǔ, sān suì bú dí。”

Buttocks stocked in woods, step into steep valley, three years of age NEG meet.

Beginning 6: Your buttocks are sore from sitting alone for a very long time on a tree stump in a secluded valley.

(The I Ching, or Book of Changes - Yi Jing I. 47.)

(21)《渐·九五》: “鸿渐于陵, 妇三岁不孕, 终莫之胜, 吉。”

《Jiàn · jiǔ wǔ 》: "hóng jiàn yú líng, fù sān suì bú yùn, zhōng mò zhī shèng, jí。

Wild goose gradually towards the hillock, woman three years NEG pregnant, final no one MOD win, weal.

Fifth 9: The wild goose gradually advances towards the hillock. The woman does not fall pregnant for three years, but in the end, nothing can hinder it and all will be well.

(The I Ching, or Book of Changes - Yi Jing I. 53.)

As illustrated in example (21) it means that Hongyan (the wild goose) gradually entered the hill; the wife had difficulty falling pregnant for many years, but in the end, no one could stop her from getting pregnant, fortune (Liao, 2012, 2015). “三岁不孕 sān suì bú yùn" is not to say only three years of infertility, and that in the fourth year she was pregnant, but that falling pregnant was difficult, and so for many years she could not fall pregnant.

(22)《丰·上六》: “丰其屋, 部其家, 圃其户, 阅其无人, 三岁不觌, 凶。”

《Fèng · shàng liù»: "fêng qí wū, bù qí jiā, pù qí hù, qù qí wú rén, sān suì bú dí, xiōng。"

Award his home, open his door, peep his window, hear MOD no one, three years of age NEG see, woe.

Top 6: Abundance to a degree where the [luxury] of your house is screened off from the [outside world]. It is bad if you peer into the house and it is quiet with no people, and there has been no one visiting for a long time.

(The I Ching, or Book of Changes - Yi Jing I. 55.)

Regarding the expression of “三岁 sansui three years old” in these examples, whether they are all specific time usage or long time expressions meaning a long time, there have been different explanations provided by various scholars. Huang and Zhang (2007) held that “三岁” in examples (18) and (19) means specifically three years, while “三岁” in examples (20) and (21) just means many years or a long time; Jin and Lü (2005) considered “三 岁” in examples (19) and (22) as meaning “many years.” In our opinion all examples with “三岁” here refer to the meaning of “many years or a long time." The “three 三” here is not a real reference (实指 shizhi), nor is it a “two plus one (sum). " It is a general expression which means “a lot." “三岁” refers to years of age, but in fact it is not the specific age.

(23)《临》卦辞: “元亨, 利贞。至于八月有凶。”

《Lín》guà cí : "yuán hēng, lì zhēn。 zhì yú bā yuè yǒu xiōng。”

Very smooth, benefit harmony. Arrive in August have misfortune.

To oversee [things] is a basic requirement of making things go well. It will be beneficial to [ensure that everything] is correct. Otherwise, when the eighth month arrives there will be misfortune [of a bad harvest].

(The I Ching, or Book of Changes - Yi Jing I. 19.)

Here, the “八ba Eight” of “八月bayue August," is an ordinal number, and “August” represents the eighth month. Naturally, it is a specific usage. It is worth pointing out that the meaning of the word “月” has changed from the changing shape of the moon (for instance, “月几望”) to a measurement unit for time (for instance, “八月”).

(24) 《复》卦辞: “复, 亨, 出入无疾, 朋来无处。反复其道, 七日来复, 利有做往。”

《Fù》 guà cí : "fủ, hēng, chū rù wú jí, péng lái wú jiù。 făn fù qí dào , qū rì lái fù, lì yǒu yōu wăng。" 
$\mathrm{Fu}$, smooth, out and in no illness, friends come no disaster. Repeat again this rule, seven days come return, good for have go towards.

Returning [from a journey] that went well, you went out and came back unharmed. When friends have come and all went well, they turn back and return to their own way. Then, after seven days they return again. It is beneficial to have a destination to travel towards.

(The I Ching, or Book of Changes - Yi Jing I. 24.)

Social and cultural factors have an important impact on the formation of time. As illustrated in example (24), “七 日来复 qī rì lái fü" means “I will reply in a few days." It is not the specific seven days usage, but just indicates that time is not long but cyclical. “七日 qiri seven days” in ancient China was usually connected with a cyclic concept of time.

(25)《震·六二》: “震来厉, 亿丧贝。跻于九陵, 勿逐, 七日得。”

《Zhèn · liù èr》: "zhèn lái lì, yì sàng bèi o jī yú jiǔ líng, wù zhú, qū rì dé。”

Thunder come strong, billion lose treasure, surpass at Mount Jiuling, NEG go further, seven days gain.

Second 6: Thunder is coming; it can be dangerous [but only one in] a million would strike us. It is just like if you lose some money, then just climb over nine hills not seeking it; after seven days you will get [money again].

(The I Ching, or Book of Changes - Yi Jing I. 51.)

Here example (25) means that "Thunder comes suddenly, there will be danger. It is estimated that you will lose money; climb and look up, do not worry about it, and soon the lost things will return to you." (Liao, 2012, 2015). Judging from the calmness of “勿逐 wuzhu Do not follow," “七日 qiri seven days" means that the time is not long. It is only a few days, but not necessarily seven days.

(26) 《既济·六二》: “妇丧其茀,勿逐, 七日得。”

$$
\text { 《Jì jì · liù èr》: "fù sàng qí bó, wù zhú, qī rì dé。” }
$$

Woman lose her ornament, not look for, seven days gain.

Second 6: The woman loses her carriage curtain but she should not look for it, she will get [another] after a few days.

(The I Ching, or Book of Changes - Yi Jing I. 63.)

As illustrated in example (26), it means that the woman lost her jewelry and did not have to pursue it. It will be recovered and gained again in a few days (Liao, 2012, 2015). "Seven days" here cannot be said to be a real number (实数 shishu). It is just referring to seven days as a general period of time, and it could be a few days or many days. Besides these examples, we can find other similar examples in the YiJing text such as the following:

(27)《明夷·初九》: “明夷于飞, 垂其翼; 君子于行, 三日不食。有做往, 主人有言。”

《Míng yí · chū jiǔ»: "míng yí yú fề, chuí qí yì ; jun zì yú háng, sān rì bú shí yǒu yōu wăng, zhǔ rén yǒu yán。”

Ming yi at fly, left down its wing. Gentleman at walk, three days NEG eat. Have go on, master have words to say.

Beginning 9: [While on a campaign] to enlighten barbarians, [although progressing like you were] flying [you should] lower your wings [and come down]. When the wise person is walking for three days he doesn't eat because he has a set goal. However, his landlady has something to say [about not eating her food].

(The I Ching, or Book of Changes - Yi Jing I. 36.)

Here, “三日不食 sanri bushi Not eating for three days” in Example (27) does not mean that there are only three days of eating nothing, but that there are many days of eating nothing. The “三日 sanri three days" here is not specific usage, but expresses the meaning of many days. There are other examples like this, such as (32) and (33) below.

(28)《既济·九三》: “高宗伐鬼方, 三年克之, 小人勿用。”

《Jì jì · jiǔ sān 》: "gāo zóng fá guĭ fāng, sān nián kè zhī, xiăo rén wù yòng。”

GAO ZONG attack devil land, three years win it, small men no use.

King Wu Ding attacked the devil's land and could do it in three years; [for such a task] less capable men cannot be used.

(The I Ching, or Book of Changes - Yi Jing I. 63.) 
Here, there is still a conflicting view about “三年 sannian three years” in Example (28). Wang Bi (226-249) and Kong Yingda (574-648) argue that it really represents three years (specific usage) (Lin,1999), but there is no convincing evidence for this interpretation. According to the book 今本竹书纪年 Jin Ben Zhu Shu Ji Nian, “武 丁三十二年伐鬼方, 次于荆, 三十四年, 王师克鬼方, 氐羌来宾Wǔdīng sānshi'èr nián fá guǐ fāng, cì yú jīng, sānshísì nián, wángshīkè guĭ fāng, dī qiāng láibìn," from the key words “三十二年sanshi er nian thirty two years” to “三十四年 sanshi sinian thirty four years," we can count that it is just "three years” (Gao, 2007). However, Yao Peizhong (1792-1844) of the Qing Dynasty had already pointed out that the book 今本竹书纪年 Jin BenZhu Shu Ji Nian is also based on the ShiJing and the YiJing (Yao, 1995). That is to say, the idea of 今本 竹书纪年Jin BenZhu Shu Ji Nian cannot be found in the 古本竹书纪年Gu Ben Zhu Shu Ji Nian, which was compiled from the texts of 既济JiJi in the YiJing and 荡Dang in the ShiJing. Yao's statement that it is counted from “三十二年 sanshi er nian thirty two years” to “三十四年 sanshi sinian thirty four years” is invalid. Cheng (2011) analyzed and compared various aspects of the system, volume, year, text, academic, quotations, compilations, engravings, and calendar. He held that 今本竹书纪年Jin BenZhu Shu Ji Nian is developed from the 古本竹书纪年 Gu Ben Zhu Shu Ji Nian (when it is lost, missing some parts), so we cannot judge that “三 年” is just from “三十二年 sanshi er nian thirty two years” to “三十四年 sanshi sinian thirty four years.” As illustrated in example (29), “三年” is also not a specific period of time.

(29)《未济·九四》: “贞吉, 悔亡。震用伐鬼方, 三年有赏于大国。”

《Wèi jì . jiǔ sì 》: "zhēn jí, huľ wáng。 zhèn yòng fá guĭ fāng, sān nián yǒu shăng yú dà guó。”

Persist weal, regret lose. Use attack devil land, three years have reward by a great country.

Fourth 9: Correct things for the better then regret will vanish. Use great power when attacking the Devil's land. It may take three years, but then you will have the reward of a greater country.

(The I Ching, or Book of Changes - Yi Jing I. 64.)

In short, one quite striking fact that emerges from the data is that the quantifiers in the YiJing text that express time are definite or certain(specific usage), such as “日 ri day,” “岁 sui age,” “年 nian year,” “月 yue month.” The cardinality of expressing time is uncertain, and is often not specific, such as "three, seven, ten." However, when an Ordinal number is used for expressing time, it is for a real specific usage, for example “八月 bayue August." Therefore, the “三岁 sansui three years old, 三年 sannian three years, 十年 shinian ten years, 三日 sanri three days and 七日 qiri seven days" are not “实数 shishu real numbers," but are “虚数 xushu approximations or imaginary numbers." I will talk about the details of this point in another paper. "Three years old, three years and ten years" have the meanings of several years. "Three days and seven days" mean a few days. One quite striking fact that emerges from the data is that this kind of usage in ancient Chinese is metaphoric temporal usage: that is, our understanding of time is essentially metaphoric.

\subsection{Expressing the Time Concept with the Branches and the Stems}

The token and frequency of the third category is $2 / 37$. It is considered as event-based intervals as in the following examples. The original method of recording time in ancient China was characterized by the fact that time was usually not recorded as numbers, but as events. For the ancient people, time was a combination of events that were occurring or that had occurred.

(30)《革》卦辞: “巳日乃孚。元亨利贞,悔亡。”

"Gé》 guà cí : "sì rì năi fú 。 yuán hēng lì zhēn, huĭ wáng。"

Si day change. Very smooth, benefit persist. Regret lost.

Change. When the [right] day has arrived there will be confidence in change. [This is the very] foundation of a successful [transition]. It is beneficial to correct things, then regret will go away.

(The I Ching, or Book of Changes - Yi Jing I. 49.)

(31)《革·六二》: “巳日乃革之, 征吉,无处。”

《Gé · liù èr》: "sì rì năi gé zhī, zhēng jí, wú jiù。',

Si day just transforms, march weal, no fault.

Second 6: When the right day has arrived then change; to attack [at that time] is good and there will be no failure.

(The I Ching, or Book of Changes - Yi Jing I. 49.)

As illustrated in examples (30) and (31), “已日 siri Day Si” refers to the Shangsi festival on March 3 in China. 
The ancient people often use heavenly stems (天干 tiangan) and earthly branches(地支 dizhi) to record the time, including day, year, month and hour. The combination of stems and branches is the result of the yin and yang calendar combination, which was developed relatively well in the Xia, Shang and Zhou Dynasties. The history of numbers and time in ancient China is closely related to stems and branches. To some extent, stems and branches are one kind of natural calendar. Calendars and clocks are cognitive artefacts that play important roles in the concept of time. These artefacts were produced with the intention to measure time in our society in a precise way (weeks, months, years, seconds, minutes, hours and so forth) (Silva Sinha et al., 2017). In addition to recording the year of the dynasty, the stems and branches can also represent the order of the month, the day, and the hour, repeatedly and in a cyclical manner.

\subsection{Describing the Time Concept with the Activities of the Crowd or a Certain Group and Certain Social Customs (Event-Based Time)}

The token and frequency of the fourth category is $2 / 37$. This is a method of expressing the number of points in time with the activities of the crowd or certain groups and certain social customs. On the surface it is the representation of time, which implies a certain sense of distance according to the event-based context. To some extent, this is one kind of time-space mapping (two directions), for example, reckoning of distance by quantifying the number of days of a journey by horse. Measurement of distance in terms of time reckoning is very common in most languages, including in ancient Chinese. Time is related to the operation of the celestial bodies, such as the sun, the moon and the stars, but it is not only this kind of operation; time should relate to the operation of all objects. The time concept in the YiJing is one kind of reckoning usage of counting event-based time as in the following examples.

(32)《盅》卦辞: “盅, 元亨, 利涉大川。先甲三日, 后甲三日。”

《Gǔ» guà cí : "gǔ, yuán hēng, lì shè dà chuān。xiān jiă sān rì, hòu jiă sān rì。”

$\mathrm{Gu}$, very smooth, benefit from crossing the great river. Before Jia three days, after Jia three days.

Harmful [ways]. What we basically want is for things to go well. It is of benefit to cross the great river. [Prepare] for three days before commencement, and after [settle on the other bank] for three days.

(The I Ching, or Book of Changes - Yi Jing I. 18.)

In this example, “先甲三日 xianjia sanri three days before Day Jia and 后甲三日 houjia sanri three days after Day Jia" is one kind of metaphorical expression of space-time, especially focusing on "xian and hou," which is also space in terms of time (time-space usage). Here "xian and hou/front and back" means "before and after," which is the usage of complementary pairs to express the concept of space. They can be used as auxiliary words, which is different from the modern Chinese. The event here is something that happens or takes place, and the main feature for event-based time is the event itself, such as life stages, intervals of the day and night and seasons. The length of the event-based intervals is not only measured numerically, but metaphorically. Of course, understanding time is not limited to motion: time is also understood as space, as money, or as a commodity, among other mappings (Ahrens \& Huang, 2002). Passage metaphors may involve explicit use of motion verbs such as "come, go, pass, arrive, and so on"; they may rely instead on the metaphoric interpretation of adverbial phrases such as "the year ahead," and can be stative and orientational as well as dynamic, sometimes involving fictive motion (Talmy, 1999). Example (33) shows us a case consisting of metaphoric interpretation, and the most important metaphorical source domain is that of space.

(33) 《巽·九五》: “贞吉,悔亡,无不利,无初有终。先庚三日,后庚三日,吉。” 《Xùn · jiǔ wǔ》: "zhēn jí, huľ wáng, wú bú lì, wú chū yǒu zhōng oxiān gēng sān rì, hòu gēng sān rì, jí。”

Persist weal, regret lose, without NEG benefit, without beginning have end. Before Geng three days, after Geng three days.

Fifth 9: Correct things for the better; then regret disappears and all is beneficial. Not much of a beginning but there will be an end. Allow three days before the seventh day and three days after; this way things will turn out well.

(The I Ching, or Book of Changes - Yi Jing I. 57.)

As shown in (32) and (33), “先 xian” means before, while “后 hou” means after. They are combined with their own objects that represent time, indicating that the action happens before (after) the event or object represented by the preposition object. Both of these examples use the “先后 xianhou before and after, 上下 shangxia up and down + number of time slots" construction to show the conceptualization of time in ancient China. In modern Chinese, we still use this kind of construction, for example, fifteen days before and after, five thousand years up 
and down. In this type, the “先 before and 后 after+ X" construction is used more, while use of “上 up and 下 down $+\mathrm{X}$ " construction is very limited. "Before and after" is the synthesis of the position words, which refers to the spatial range of the front and the back in the position sense; correspondingly, the "before and after X" construction also refers to a time range including before and after X, and thus belongs to the time structure representing the time period in terms of the meaning function. The conceptual metaphor TIME AS SPACE is conceptually well motivated.

What is more interesting is that these two examples obviously lack a predicate structure from the view of sentence structure, only leaving the time phrase adverbials such as “先甲三日，后甲三日three days before Day Jia and three days after Day Jia” or “先庚三日,后庚三日 three days before Day Geng, three days after Day Geng," which is also one feature of the YiJing syntax structure.

The original method of recording time is characterized by the fact that time is usually not recorded by numbers, but by events. For the ancient people time was a combination of events that were occurring or had occurred. I claim that parts 3.3 and 3.4 mainly belong to the category "Event based intervals," such as “巳日 siri Day Si," “先甲三日 xianjia sanri three days before Day Jia and 后甲三日 houjia sanri three days after Day Jia." Meanwhile the metaphorical expression "xian and hou/front and back" indicates another category "Metaphoric temporal usage," which is a metaphoric expression of time, such as "a long time" or "quasi-calendar time." Xian and hou are considered as the basic temporal sequence words, which are also expressed by spatial expression. TIME is perceived as the motion event, which is not only extended in space, but also in time. Ahrens and Huang (2002) also argued and identified that the concept of time passing should be understood as motion.

\subsection{Directly Use "Year, Month, Day, etc." to Record Time}

The token and frequency of the fifth category is 7/37. It should be noted that examples (34), (35) and (36) all use “终日 zhongri all day” to record time, as illustrated below:

(34)《乾·九三》: “君子终日乾乾, 夕惕若, 厉, 无处。”

《Qián · jiǔ sān》: "jun zǐ zhōng rì qián qián, xī tì ruò, lì, wú jiù。”

Gentleman all day struggle, evening on guard, harmful, no disaster.

Third 9: The wise person is active all day long, and is even on guard in the evening. It would seem this could be harmful but is [in this case] not a mistake.

(The I Ching, or Book of Changes - Yi Jing I. 01.)

(35) 《豫·六二》: “介于石, 不终日,贞吉。”

《Yù · liù èr》: "jiè yú shí, bú zhōng rì, zhēn jí。"

Protect behind stone, NEG all day, persist weal.

Second 6: Hide behind rocks, but don't stay there all day, [go on and] correct things for the better.

(The I Ching, or Book of Changes - Yi Jing I. 16.)

(36) 《既济·六四》: “繻有衣枷, 终日戒。”

《Jì jì l liù sì»: “xū yǒu yī jiā, zhōng rì jiè。”

Wearing clothes worn, all day worry.

Fourth 6: Your fine colored silk cloth has been worn [for so long it is nearly] worn-out. Towards the end of its days you must be careful [not to rip it].

(The I Ching, or Book of Changes - Yi Jing I. 63.)

In these three examples “终日zhongri days” includes day and night. The “日ri day” in the YiJing often indicates a day and night, that is, one whole day. It is used to measure the time unit of the sun's sunrise and sunset, that is, the day we are talking about, or one day and night; and because the sun comes out or rises during the day time, “日 ri day" refers to “白昼 baizhou day and night." At the same time, we can also find that there are some special words, such as “昼 zhou day time," “夜 ye night time," “夕 xi dusk evening” and “朝 zhao morning” in the following examples:

\section{昼zhou:}

(37) 《晋》卦辞: “晋, 康侯用锡马蕃庶, 昼日三接。”

《Jìn》 guà cí: "jìn, kāng hóu yòng xī mă fān shù, zhòu rì sān jiēe, 
Kanghou use horses breed a multitude, day and night three times meet.

The Lord of Kang herewith awards horses in multiples; during the day there were three engagements. (The I Ching, or Book of Changes - Yi Jing I. 35.)

夜 ye:

(38)《夫夫九二》: “惕号, 莫夜有戎, 勿恤。”

《Guài ·jiǔ èr》: "tì hào, mò yè yǒu róng, wù xù。”

Great scream, in evening have army, not worry.

Nine in the Second: An apprehensive scream. In the evening and night there are enemies. Do not worry. (The I Ching, or Book of Changes - Yi Jing I. 43.)

夕 $x i$ :

(39)《乾·九三》: “君子终日乾乾, 夕惕若厉, 无处。”

《Qián · jiǔ sān》: “jun zǐ zhōng rì qián qián, xī tì ruò lì, wú jiù。”

Gentleman all day struggle, evening fear as if danger, no trouble.

Nine in the Third: All day long the superior man is creatively active. At nightfall his mind is still beset with cares. Danger. No blame. (The I Ching, or Book of Changes - Yi Jing I. 01.)

In oracle bones language, “月 yue moon” and “夕 xi nightfall” have the same shape structure (the shape of the moon like $D$. words “月 $y u e$ ” and “夕 $x i$." The period of the moon shape's change is about 30 days: during this change, the ancestors formed the concept of the time when the moon was missing, or when it was full, but still named it after the “月 yue moon."

\section{朝 zhao:}

(40)《讼·上九》: “或锡之幋带, 终朝三裭之。”

《Sòng · shàng jiǔu》: "huò xī zhī pán dài, zhōng zháo sān chǐ zhī。"

Or award him leather belt, final morning three times strip it.

Top nine: Even if by chance a leather belt is bestowed on you, by the end of a morning it will have been snatched away three times.

(The I Ching, or Book of Changes - Yi Jing I. 06.)

In contrast, as shown in (40), the case of “朝zhao morning” is just the opposite of “夕xi evening," which shows that the sun has come out, and the moon has not yet fallen - the early morning scene. Generally speaking, the ancient people differentiated the daytime and evening by the movement of the sun and moon, which is also the original way of conceptualization of time.

In short, judging from the available data, it appears that the conceptualization of time in the YiJing is mainly event-based time, which can be summarized as the following categories: 1. Metaphoric temporal usage, which is a metaphoric expression of time, such as "a long time" or "quasi-calendric time"; 2. Concepts of time, involving Quantification of time, for example, the processes of waxing, waning, declining and growing that illustrate the quality of alteration associated with time; 3. Event based intervals, such as “已日 siri Day Si” or “先甲三日 xianjia sanri three days before Day Jia and 后甲三日 houjia sanri three days after Day Jia"; 4. The propitious or opportune time, which is the notion of time as the right moment to do something, or the right time which gives us a chance to engage in the activity at the right time once it brings good fortune. This category is closely related with “吉 $j i$ weal" and "凶 xiong woe" in YiJing culture. We will discuss this issue in detail in the future.

\section{Discussion}

In this part, I will discuss my findings, compare them with the existing literature, and address issues such as its contributions and limitations. I argue that metaphors regarding time could be more motivated. I explore in more depth the motivations or underlying reasons of encoding time in different ways.

\subsection{Metaphorical Expression}

Days, weeks, months, and years can correspond to periodic recurrences of rites, feasts, and ceremonies in ancient 
China (Silva Sinha et al., 2012). Here, both the expression of “先甲三日, 后甲三日 xianjia sanri, houjia sanri three days before Day Jia, three days after Day Jia” and “先庚三日, 后庚三日 xiangeng sanri, hougeng sanri three days before Day Geng, three days after Day Geng" in the YiJing are the temporal concepts on the surface, but from the event-based context-What we basically want is for things to go well. It is of benefit to cross the great river, keeping the proper distance is crucial. What kind of distance, the distance of three days before and after Jiari (the record day method of using stems and branches in ancient China), is the abstract distance indicated in "[Prepare] for three days before commencement, and after [settle on the other bank] for three days." In this way, we can reckon some distance by quantifying the number of days based on events and activities.

How do we know if it is distance or just waiting for time? Certainly, the use of "xian and hou/front and back" is a metaphorical expression in which space is mapped to time. Sinha and Bernárdez (2015) found time-space mapping in ancient usage, which is the reference to a journey by horse. This means that we do not always metaphorically express time in terms of space; we sometimes express spatial distance metaphorically in terms of time. There is a mapping from time to space. Maybe "three days before or after" is also the representation of the linguistic anchor trajectory in the YiJing that uses complementary pairs. As in other cases, we often come across similar pairs in the YiJing.

\subsection{Space-Time Metaphor}

We further propose that “往 wang and 来 lai" usages in the YiJing, such as in examples (11), (24), (25) and (27), especially in relation to metaphoric usage, include not only temporal metaphors, but also space-time metaphors. Space and time are linked to each other in human thinking. Just like the above analysis of the related example interpretations of these directional motion verbs in the YiJing, which contain some specific or abstract events, consisting of the motions moving from one location to another, it will cover not only a certain space (like the motion path of 往 wang or 来 lai), but also a certain amount of time (the time it takes to move from one location to another). They can be called space-time metaphors. In other words, we would expect that the transfer from time to space should be as common as the transfer from space to time.

$\mathrm{Xu}$ (2016) discussed the vertical time expressions in ancient Chinese, such as “上世 shangshi in previous eras,” “上古 shanggu in ancient times," “上旬 shangxun the first ten days," etc., especially as they are used in pre-Qin documents. She held that expressions with spatial meaning often evolve into expressions with temporal meaning in natural languages. The ancient Chinese possessed horizontal time expressions ( like "前 qian front" and “后 hou back"), as well as vertical time expressions (like “上 shang up" and “下 xia down"). The language in the YiJing is different. We can also find some horizontal time expressions that use xian and hou, for example, “先甲三日 xianjia sanri three days before Day Jia and 后甲三日 houjia sanri three days after Day Jia.” However, vertical time expressions cannot be found in the YiJing.

From the above randomly selected 37 Hexagram Judgments (gua) and Linear Judgments (yao), we can summarize the time concepts in the YiJing: 日ri day、月yue month、月望 yue wang the moon waxing to the full、年nian year、岁sui year、甲jia、已si、庚geng、日是rize sundial(tool)、日中 rizhong midday/noon、昼 日zhouri daytime. We can also classify them into the followings in terms of different standards:

Natural time: 日day, 月month, 年year...; Phases of the moon: 月望the moon waxing to the full...; Period of day: 昼日daytime, 日中midday/noon...; Conventional time based on event: 先甲/庚三日three days before DayJia/ Geng,后甲/庚三日 three days after Day Jia/Geng ...; Life stage (Human): 岁year of age...; and event based time:巳日Day Si, 日旲 sundial(tool)....

Judging from the available data, it appears that the four seasons do not appear in the YiJing text, which is worth pointing out and is something that we will explore in the future. To sum up, this paper helps us understand the way in which concepts of time in the YiJing are organized and expressed in terms of language structure and cultural practice.

\section{Conclusion}

In this paper, a priming corpus study of the conceptualization of time was conducted based on the Shanghai Museum version of the YiJing text. From the priming corpus analysis, we can easily find five classifications and the related four categories. "Natural time" and "Cardinal number + temporal unit word" were the most common temporal concepts in the YiJing; that is, the so-called natural or agricultural basis of event-based time intervals, which is used for certain historical, cultural and agricultural factors in that period. The time consciousness of the ancestors in the Zhou Dynasty presented a sense of "timely chance," that is, sometimes suitable or not suitable for doing something, especially in the natural or agricultural world in the Zhou Dynasty. The ancestors of the Zhou Dynasty believed that the so-called timely chance is to do the right thing at the right time, and to avoid 
losing the right time or choosing the wrong time. These examples mentioned in this paper demonstrate how the sun, the moon, the stars and natural and social happenings index the event-based time intervals, and how they were used by the ancient people to reckon time.

The present paper evaluates the claim that the original method of recording time is characterized by the fact that most are not recorded by numbers, but by events. For the ancient people, time was a combination of events that were occurring or that had occurred. Time in the YiJing is also a form of material existence. It is a reflection of the continuity and order of the movement of objective things. However, due to the particularity of time itself, it has no intuitive image, and there is no analyzer that specifically perceives time. To directly perceive time, we must always recognize and reflect on it by means of a medium (event-based) or by metaphors that directly reflect the time process, such as the periodicity of nature (the time required for the moon to return to a relative position or to return to the same state), changes (alternating day and night, sun rising and setting, moon waxing and waning) the age; and the number of years.

\section{Acknowledgement}

This research was financially supported by The General grant project of Hunan Provincial Social Science Achievements Review Committee in 2019 (Grant Number: XSP19YBZ080)—A Study of Time and Space Language Representation in Ancient China-Taking ShiJing and YiJing as an Example; Humanities and Social Science Fund of Ministry of Education of China in 2017 (Grant Number: 17YJCZH221). The author would like to thank the referees and editors for their valuable comments, and support from CSC in China and CRLAO, Inalco, in France.

There is no conflict of interest to publish this paper in this Journal.

\section{References}

Abu-Shams, L., \& González-Vázquez, A. (2014). Juxtaposing Time: An Anthropology of Multiple Temporalities in Morocco. Revue des mondes musulmans et de la Méditerranée, 136, 33-48. https://doi.org/10.4000/remmm.8817

Ahrens, K., \& Huang, C. R. (2002). Time passing is motion. Language \& Linguistics, 3, 491-519.

Baynes, C. F., \& Wilhelm, R. (trans.) (1997). The Yi Ching. New Jersey: Princeton University Press.

Birth, K. K. (2012). Objects of Time: How Things Shape Temporality. New York: Palgrave Macmillan. https://doi.org/10.1057/9781137017895

Boroditsky, L., \& Gaby, A. (2010). Remembrances of times East: absolute spatial representations of time in an Australian aboriginal community. Psychological Science, 21(11), 1635-1639. https://doi.org/10.1177/0956797610386621

Cheng, P. S. (2011). A Review of Studies on the Authenticity and Value of the Zhushu jinian. Research trends of Chinese history, 6, 25-30.

Edward, L. S. (2014). Unearthing the Changes: Recently Discovered Manuscripts of the Yi Jing (I Ching) and Related Texts. New York: Columbia University Press. https://doi.org/10.7312/shau16184

Gao, H. (2007). The Modern Interpretation of the Ancient Jing of Zhouyi. Beijing: Zhong Hua Book Company. https://doi.org/10.3389/fpsyg.2013.00554

Huang, C., \& Zurcher, E. (1995). Time and Space in Chinese Culture. E. J. Brill.

Huang, S. (2016). Time as space Metaphor in Isbukun Bunun: A Semantic Analysis. Oceanic Linguistics, 55(1), 1-24. https://doi.org/10.1353/ol.2016.0002

Huang, S. Q., \& Zhang, S. W. (2007). Translated Notes of the Zhouyi. Shanghai: Shanghai Guci press. https://doi.org/10.1142/t018

Hubert, H. (1999). Essay on Time: A Brief Study of the Representation of Time in Religion and Magic. Oxford: Durkheim Press.

Jin, J. F., \& Lü, S. G. (2005). The revised version of the Book of Changes. Shanghai: Shanghai Guji press.

Levine, R. V. (1998). A Geography of Time: The Temporal Misadventures of a Social Psychologist (Revised ed.). New York: Basic Books.

Levinson, S. C. (2003). Space in Language and Cognition: Explorations in Cognitive Diversity. Cambridge: Cambridge University Press. https://doi.org/10.1017/CBO9780511613609 
Levinson, S. C., \& Majid, A. (2013). The Island of Time: Yélî Dnye, the Language of Rossel Island. Frontiers in Psychology, 4. https://doi.org/10.3389/fpsyg.2013.00061

Li, X. Q. (2005). Unearthed Artifacts and the Study of Zhou Yi. Qilu Journal, 2, 5-9.

Liao, M. C. (2012). The Fifteen Lectures on Zhou Yi Jing and Commentary books. Peking University Press.

Liao, M. C. (2015). The Imagination and Reality of the Time Expressed in the Zhou Yi's Hexagrams and Liner statements. The Social Science, 08, 11-18.

Lin, H. S. (1999). Explore into Yi and Commentary books. Jiji Hexagram (water and fire). Tai bei: Culture, history and philosophy press.

Majid, A., Gaby, A., \& Boroditsky, L. (2013). Time in terms of space. Frontiers in Psychology, 4, 554. https://doi.org/10.3389/fpsyg.2013.00554

Minkowski, H. (1964). Space and time: Minkowski's papers on relativity. Canada: Minkowski Institute Press.

Moore, K. E. (2006). Space-to-time mappings and temporal concepts. Cognitive Linguistics, 17(2), 199-244. https://doi.org/10.1515/COG.2006.005

Moore, K. E. (2014). The two-Mover hypothesis and the significance of 'direction of motion' in temporal metaphors. Review of Cognitive Linguistics, 12(2), 375-409. https://doi.org/10.1075/rcl.12.2.05moo

Núñez, R. E., \& Cornejo, C. (2012). Facing the Sunrise: Cultural Worldview Underlying Intrinsic-Based Encoding of Absolute Frames of Reference in Aymara. Cognitive Science, 36(6), 965-991. https://doi.org/10.1111/j.1551-6709.2012.01237.x

Núñez, R. E., \& Sweetser, E. (2006). With the Future Behind Them: Convergent Evidence from Aymara Language and Gesture in the Crosslinguistic Comparison of Spatial Construals of Time. Cognitive Science, 30(3), 401-450. https://doi.org/10.1207/s15516709 $\operatorname{cog} 0000 \_62$

Núñez, R., \& Cooperrider, K. (2013). The tangle of space and time in human cognition. Trends in Cognitive Sciences, 17(5), 220-229. https://doi.org/10.1016/j.tics.2013.03.008

Núñez, R., Cooperrider, K., Doan, D., \& Wassmann, J. (2012). Contours of time: Topographic construals of past, present, and future in the Yupno valley of Papua New Guinea. Cognition, 124(1), 25-35. https://doi.org/10.1016/j.cognition.2012.03.007

Postill, J. (2002). Clock and Calendar Time: A missing anthropological problem. Time \& Society, 11(2-3), 251270. https://doi.org/10.1177/0961463X02011002005

Pu, M. Z. (2014). Zhouyi of Chu Bamboo Books in Shanghai Museum. Shanghai: Chinese and Western Bookstores.

Schieffelin, B. B. (2002). Marking Time: The Dichotomizing Discourse of Multiple Temporalities. Current Anthropology, 43(S4), S5-S17. https://doi.org/10.1086/341107

Silva Sinha, V. D. S., Sampaio, W., \& Sinha, C. (2017). The Many Ways to Count the World: Counting Terms in Indigenous Languages and Cultures of Rondônia, Brazil. Brief Encounters, 1(1), 1-18. https://doi.org/10.24134/be.v1i1.26

Silva Sinha, V. D. S., Sinha, C., Sampaio, W., \& Zinken, J. (2012). Event-based time intervals in an Amazonian culture. In L. Filipović \& K. M. Jaszczolt (Eds.), Space and Time in Languages and Cultures II: Language, Culture and Cognition (pp. 15-35). Amsterdam: John Benjamins Publishing Company. https://doi.org/10.1075/hcp.37.05das

Sinha, C., \& Bernárdez, E. (2015). Metaphors, maps, and fusions. In S. Farzad (Ed.), The Routledge Handbook of Language and Culture (pp. 309-324). London: Routledge.

Sinha, C., \& Gärdenfors, P. (2014). Time, space, and events in language and cognition: a comparative view. Annals of the New York Academy of Sciences, 1326, 72-81. https://doi.org/10.1111/nyas.12491

Sinha, C., Sinha, V. D. S., Zinken, J., \& Sampaio, W. (2011). When time is not space: The social and linguistic construction of time intervals and temporal event relations in an Amazonian culture. Language and Cognition, 3(1), 137-169. https://doi.org/10.1515/langcog.2011.006

Talmy, L. (1999). Fictive motion in language and 'ception'. In P. Bloom, M. Peterson, L. Nadel \& M. Garrett (Eds.), Language and Space (pp. 211-276). Cambridge, MA: MIT Press.

Tan, D. G. (2014). The View of Time Concept in the Zhouyi from the Perspective of Chinese and Western 
Culture Contrast. World Religious Culture, 5, 84-87.

Tenbrink, T. (2011). Reference frames of space and time in language. Journal of Pragmatics, 43(3), 704-722. https://doi.org/10.1016/j.pragma.2010.06.020

The Dictionary Editing Office, Institute of Languages, Chinese Academy of Social Sciences. (2016). Modern Chinese Dictionary. Beijing: Commercial press.

Wei, D. M., \& Wang, X. P. (2014). The Time concept in the Yijing. Modern Philosophy, 3, 85-92.

Wilhelm, R., \& Baynes, C. F. (1950). The I Ching, or, Book of changes. published for Bollingen Foundation Inc. by Pantheon Books.

Xu, D. (2016). Vertical Time Expressions in Ancient Chinese. Linguistic Science, 15(1), 1-10.

Yang, G. Y., Zhang, B. F., \& Jiang, W. H. (2007). The Modern Value of the Humanistic Time Conception of YiJing. Journal of Chongqing Institute of technology, (12), 85-88.

Yao, P. Z. (1995). The Crucial Things in the Zhouyi, Volume13. Shanghai: Shanghai Guji press.

Zhang, Z. G. (1953). The Common Knowledge of Chinese Grammar. China Youth Press.

Zhao, Y. R., \& Lü, S. X. (1979). Oral Grammar in Chinese. Beijing: Commercial press.

Zhou, R. (2000). A Cross-cultural Study of Time Metaphorical Representation. The Modern Chinese, 23(1), 5866.

Zhu, D. X. (2003). The Lectures on Grammar. Beijing: Commercial press.

\section{Copyrights}

Copyright for this article is retained by the author, with first publication rights granted to the journal.

This is an open-access article distributed under the terms and conditions of the Creative Commons Attribution license (http://creativecommons.org/licenses/by/4.0/). 